\title{
The inotropic effect of isoniazid on isolated atria of guinea-pigs
}

\author{
Peter Kabo
}

\begin{abstract}
Abstrak
Insiden gagal jantung meningkat setiap tahun, sedangkan obat yang ideal untuk gagal jantung belum ditemukan sampai sekarang. Maka penelitian untuk mendapatkan obat gagal jantung yang ideal masih dilakukan. Isoniazid (INH) telah digunakan secara luas sebagai obat anti-tuberculosis. INH memiliki struktur seperti 4-aminopiridin, suatu penghambat kanal $K^{+}$yang mempunyai efek memperpanjang fase depolarisasi sehingga meningkatkan jumlah $\mathrm{Ca}^{++}$masuk kedalam sel yang selanjutnya meningkatkan kontraktilitas miokard. Penelitian ini dilakukan untuk menguji apakah INH juga memiliki efek inotropik seperti 4-aminopiridin. Pada preparat atria marmot terpisah, INH meningkatkan kontraktilitas miokard tergantung konsentrasi. Kontraksi miokard maksimum dicapai pada konsentrasi INH $100 \mathrm{mM}$. Besarnya kontraktilitas ini ekuivalen dengan yang ditimbulkan oleh pemberian adrenalin 1 uM. Penyekat beta-adrenoseptor propranolol ( $I$ uM) menghambat efek inotropik dari adrenalin ( 1 uM) namun tidak berefek pada pemberian INH. Hasil penelitian ini menunjukkan bahwa INH memiliki efek inotropik positif. Efek ini bukan ditimbulkan melalui aktivasi beta-adrenoseptor di jantung oleh katekolamin akibat penghambatan monoamin oksidase, akan tetapi mungkin melalui perpanjangan fase depolarisasi sel miokard akibat penghambatan kanal $\mathrm{K}^{+}$.
\end{abstract}

\begin{abstract}
The incidence of heart failure is increasing every year, while there is no ideal inotropic agent yet available. Therefore the search for an ideal inotropic agent is still needed. Isoniazid (INH) has been widely used as an anti-tuberculosis agent that has similar structure to the $K^{+}$channel blocker 4-aminopyridine. Considering that $K^{+}$channel blocker may prolong depolarization leading to a more influx of $\mathrm{Ca}^{++}$into the cell and increase cardiac contractility, the effect of INH on cardiac contractility were investigated. In guineapig isolated atria preparations, INH produced concentration-dependent increase contractility. The maximal concentration of INH in increasing force of contractility is $100 \mathrm{mM}$. This is approximately an equieffective concentration compared to $1 \mathrm{uM}$ of adrenaline induced cardiac contractility. The difference is that INH has no effect on the rate of contraction. A non-selective beta-adrenoceptor antagonist propranolol $(1 \mathrm{uM})$ inhibits the inotropic action of adrenaline $(1 \mathrm{uM})$ but with no effect on INH $(100 \mathrm{mM})$ induced rdiac contractility. It is speculated that INH possesses a positive inotropic effect. This effect is not associated with the activation of cardiac beta-adrenoceptor by catecholamine as a consequence of monoamine oxidase inhibition, but may be through the prolongation of depolarization of the myocardial cells by blocking of $K^{+}$channels.
\end{abstract}

Keywords: Isoniazid, 4-aminopyridine, $K^{+}$channels blocker, positive inotropic

Cardiac failure is a principal complication of virtually all form of heart diseases. The incidence increases with age and carries a poor prognosis. In the Framingham study the 5-year mortality was $62 \%$ for men and $42 \%$ for women. In the UK, the overall prevalence was 15 per 1,000 . In those aged older than 65 years, the prevelence rate was even higher.'

Department of Pharmacology, Faculty of Medicine, Hasanuddin University, Ujung Pandang, Indonesia
Three general approaches in treating heart failure are: firstly to remove the underlying causes, secondly to remove the precipitating causes, and thirdly to control the congestion state by afterload reducing agents, diuretics and inotropic agents.

The goal of using inotropic agents is to improve of the heart pumping performance. Three groups of inotropic agents available nowadays are digitalis, sympathomimetic drugs and phosphodiesterase inhibitors. Unfortunately, recent data shows that none 
of these agents are safe and effective in long term trial. $^{2}$ Therefore, looking for an effective inotropic agents is needed in conquering heart failure.

Isoniazide ( $\mathrm{INH})$ is an oral anti-tuberculosis which has been use world-wide since 1945 . The structure of INH very similar to that of 4-aminopyridine, a potassium channel blocking agent (Fig.1). It has been well established that by blocking of potassium channel, 4-aminopyridine is able to prolong cell depolarization and excitation. ${ }^{3}$ In cardiac cell, prolonged depolarization may allow more calcium influx into the cell leading to increase contractility. ${ }^{4}$

In this study, the effect of INH in increasing cardiac contractility was investigated using isolated guineapig atria.

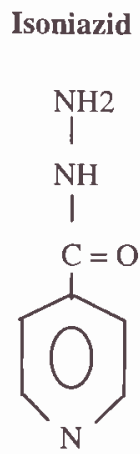

\section{4-Aminopyridine}

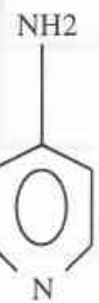

Figure 1. The chemical formulae of isoniazid and 4aminopyridine $\left(K^{+}\right.$- channel blocker $)$

\section{METHODS}

Guinea-pigs (3,00-350 g) of either sex were killed and the hearts rapidly removed. The atria were dissected free and suspended between a tissue hook and an isotonic transducer in an organ bath containing $10 \mathrm{ml}$ fresh physiological salt solution (PSS), maintained at 37 degree Celcius and bubbled with a mixture of $95 \%$ $\mathrm{O} 2 / 5 \% \mathrm{CO} 2$.

The atria were placed under basal tension of $1 \mathrm{~g} \mathrm{wt}$. The spontaneous atrial contraction were measured with a strain gauge transducer for recording the rate and force of atrial beating. The isolated atria were allowed to equilibrate for a period of $20 \mathrm{~min}$ before any experimental procedures were commenced, during each time the bathing solution was regulary exchanged. The responsiveness of the tissue was then tested by the addition to the organ bath of adrenaline ( $1 \mathrm{uM})$. Responses to addition of adrenaline was allowed to develop fully, after which the agonist was removed by repeatedly exchanging the PSS in the organ bath.

Concentration-response relationships for the positif inotropic effect of isoniazide (INH) was established by its cumulative addition to the organ bath untill obtaining the maximal response.

To examine the effect of beta-adrenoceptor blocking agent on the positive inotropic response of $\mathbb{N H H}$, the atria was exposed two times by either $\mathbf{I N H}$ or adrenaline, $30 \mathrm{~min}$ apart. Propranolol (1 uM) was added to the atrial bathing solution $15 \mathrm{~min}$ before commencing to construct the second exposure to the test agonist; it then remaining present throughhout the rest of the experiment.

Data were expressed as mean and standard error of the means $( \pm$ s.e.m), and were analyzed by paired, two-tailled Student's t-test. In all cases, level of probability $(\mathrm{P})$ of less than 0.05 was taken to indicate a statistical significance.

\section{RESULTS}

\section{Positive inotropic response of isoniazid (INH)}

The mean resting forces and contraction rate of isolated guinea-pigs atria were $0.5 \mathrm{~g} /$ weight (s.e.m. $=0.07, \mathrm{n}=5$ ) and 235 beats $/ \mathrm{min}$ (s.e.m. $=16, \mathrm{n}=5$ ), respectively.

INH (1-100 mM) produced concentration-dependent increases of contractility (Fig 2a,b) without influen-ce the rate of beating. The mean increase in force of contraction to $10,30,100$ and $300 \mathrm{mM}$ of INH were 6 $\pm 2,5 ; 26 \pm 2 ; 69 \pm 3$ and $72 \pm 4 \%$, respectively. The response being maximal at a concentration of 100 $\mathrm{mM}$.

\section{Effect of propranolol on INH-induced positive inotropic response}

Concentration of INH $(100 \mathrm{mM})$ and adrenaline (1 uM) which produced similar increases in force of contraction were selected. 
(a)

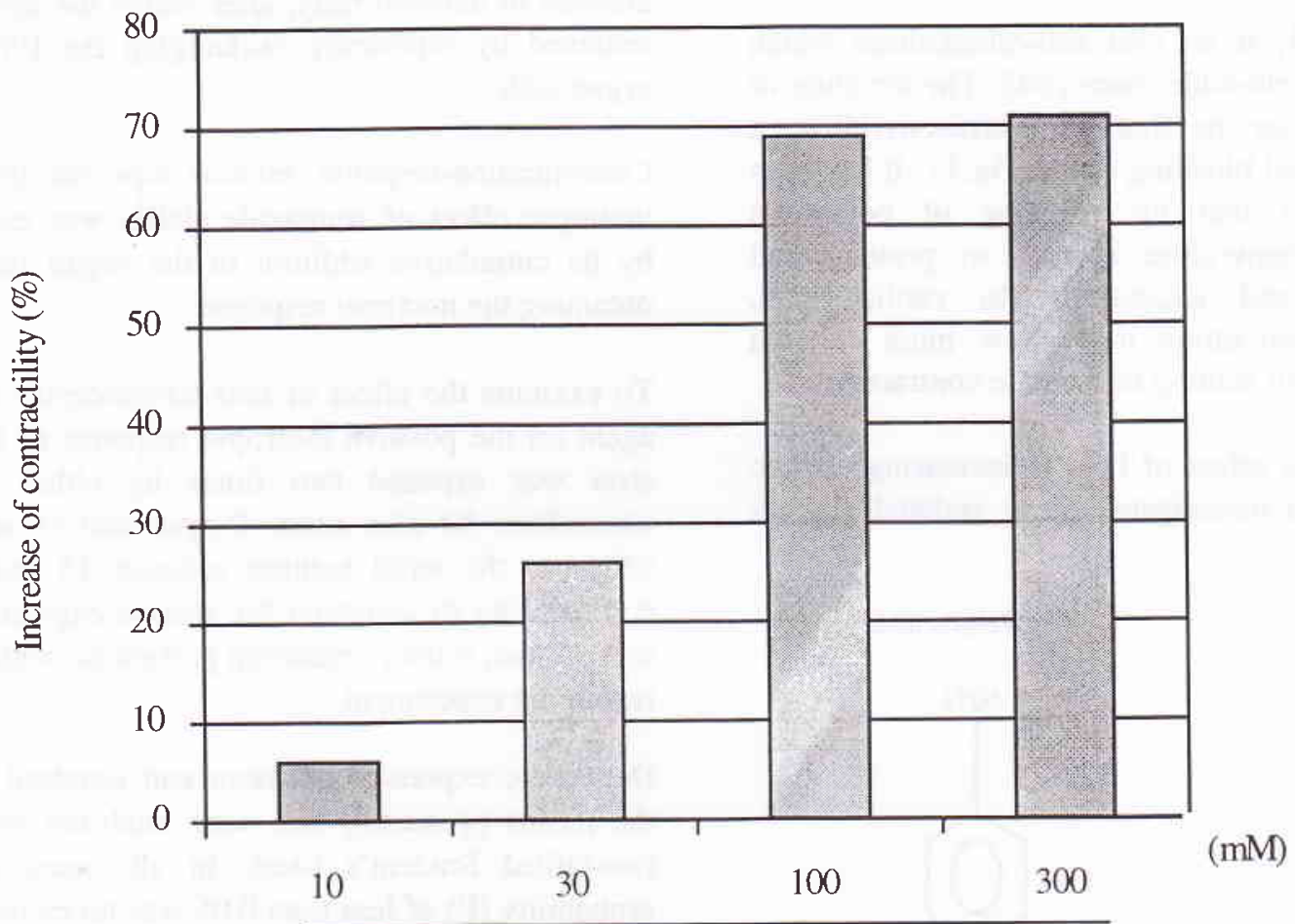

Isoniazid concentration

(b)

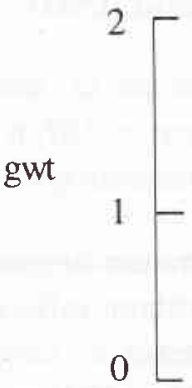

$\mathrm{INH}(\mathrm{nM})$

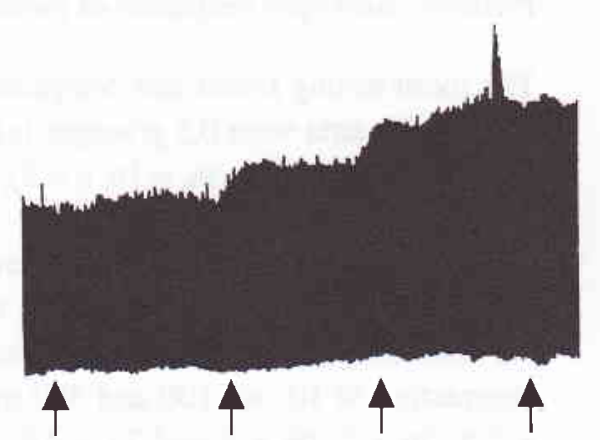

30

100

300

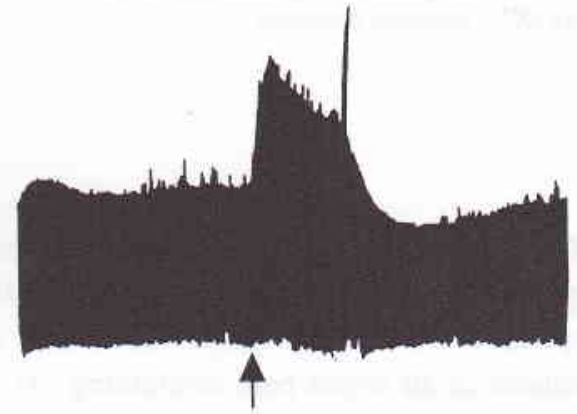

Adrenaline (1 uM)

Figure 2. The effect of isoniazid (INH) and adrenaline on cardiac contractility.

(a) INH (10-300 $\mathrm{mM})$ produced concentration dependent increase of contractility

(b) The maximal effect of INH was achieved at $100 \mathrm{mM}$ which is equipotent to adrenaline I $u M$ 
The beta-adrenoceptor antagonist propranolol $(1 \mathrm{uM})$ when introduced $15 \mathrm{~min}$ before the second exposure of guinea-pig atria had no significant effect on $\mathbb{I N H}$ $(100 \mathrm{mM})$ induced contractility $(\mathrm{P}>0.05$, unpaired $\mathrm{t}$ test). The mean value of percent increase in force of contraction to $100 \mathrm{mM} \mathrm{INH}$ alone and in the present of propranolol were $64 \pm 2,5$ and $61 \pm 3 \%$, respectively. However, propranolol significantly reduced the adrenaline $(1 \mathrm{uM})$ induced contractility $(\mathrm{P}<0.05$, unpaired $\mathrm{t}$-test). The mean value of percent increase in force of contraction to adrenaline $(1 \mathrm{uM})$ given alone and in the present of propranolol were 72 \pm 4 and $32 \pm 2,5 \%$, respectively (Fig. 3 ).

\section{DISCUSSION}

Myocardial cell membrane exhibits selective permeability to ions, positively charged such as $\mathrm{Na}^{+}, \mathrm{K}^{+}$, $\mathrm{Ca}^{++}$or negatively charged such as $\mathrm{Cl}^{-}$, creating an electrical potential across the cell membrane. The ions move across the cell membrane through ion channels.

An action potential responsible for initiating each "heart contraction" is due to a sudden increase in membrane conductance to $\mathrm{Na}^{+}$, this allows rapid influx of $\mathrm{Na}^{+}$into the cell which in turn is responsible for activating voltage-dependent calcium channels to allow $\mathrm{Ca}^{++}$enter the cell, triggers release of large amount of $\mathrm{Ca}^{++}$from sarcoplamic reticulum. $\mathrm{Ca}^{++}$ binding by troponin results in contractile activity of cardiac fibers. Thereby, there is a rapid repolarization owing to the activation of an outward $\mathrm{K}^{+}$current and cessation of the inward $\mathrm{Ca}^{++}$current. $^{5}$

It has been shown that blockade of outward $\mathrm{K}^{+}$ conductance with potassium channels blocking agent such as 4-aminopyridine enables the influx of $\mathrm{Ca}^{++}$to reinforce the applied depolarization and to become regenerative. ${ }^{6}$ In cardiac muscle, 4-amino-pyridine has been shown to increase contractility through this mechanism. ${ }^{4}$

In view of the structural similarity of INH and 4aminopyridine, $\mathbb{I N H}$ may have $\mathrm{K}^{+}$channel-blocking action and thus prolong depolarization in excitable cells. In this study, as expected, INH clearly produced a concentration dependent increase of cardiac contractility, or in other word, $\mathbb{I N H}$ possesses a positive inotropic effect. Interestingly, there was no alteration of heart beat occured in any given doses of INH. The underlying mechanism is still unknown.

Previous studies have shown that a derivative of $\mathbb{I N H}$, iproniazid, inhibited monoamine oxydase (MAO) and

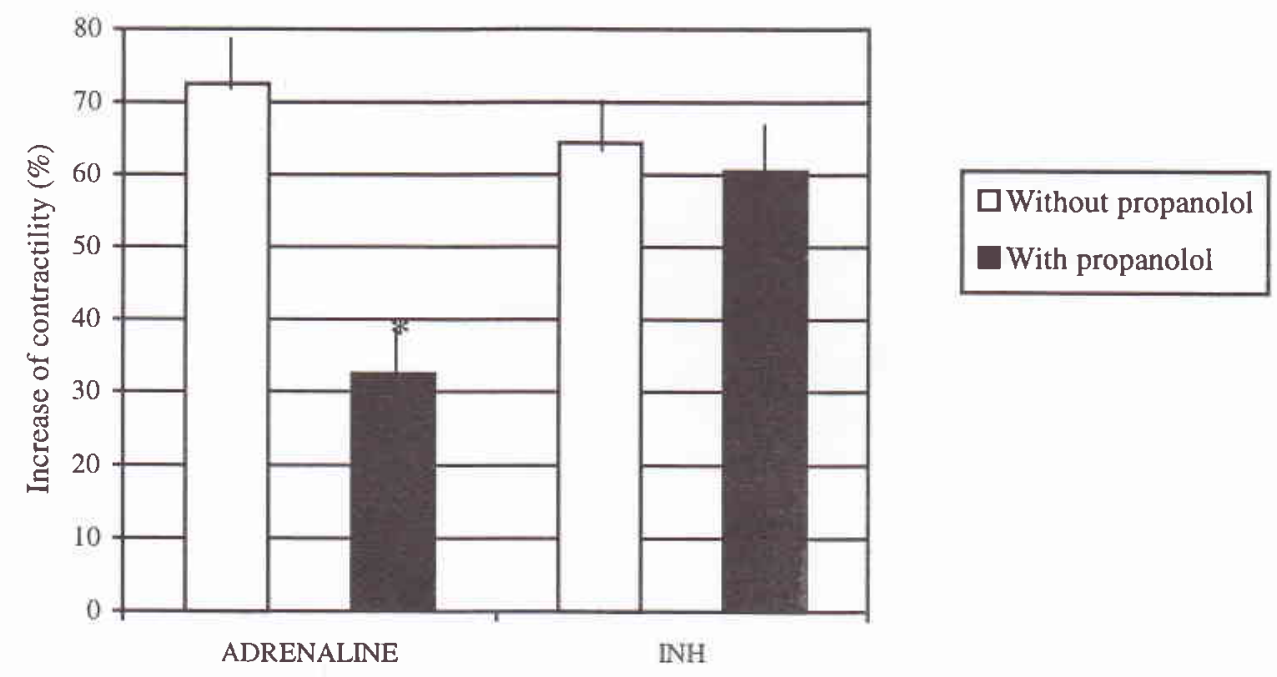

Figure 3. The effect of propranolol (1 uM) on the INH $(100 \mathrm{mM}, n=5)$ and adrenaline $(1 \mathrm{uM}, n=5)$ induced contractility. (*) indicated significant differences from corresponding control $(p<0.05)$ 
lead to an increase of catecholamine release. ${ }^{7}$ It has also been reported that euphoria or convulsion in patients with tuberculosis who receive $\mathrm{INH}$ are due to the increase level of catecholamine as a consequence of MAO-inhibition. ${ }^{8}$ Therefore, it is possible that the positive inotropic effect of $\mathbb{I N H}$ is due to the activation of the beta-adrenoceptor within the heart by catecholamine.

In order to investigate this, the positive inotropic effect of INH was tested by the presence of non-selective betaadrenoceptor antagonist propranolol. The effect of propranolol was also compared to adrenaline $(1 \mathrm{uM})$, which is approximately equieffective concentration to INH (100 mM) to induce cardiac contractility.

In the presence of propranolol, INH $(100 \mathrm{mM})$ still produced a significant positive inotropic effect. In contrast, propranolol did inhibit the positive inotropic effect of adrenaline $(1 \mathrm{uM})$. This results clearly demonstrate that $\mathbb{I N H}$ increases cardiac contractility which is not due to activation of cardiac betaadrenoceptor by increase level of catecholamine. This is in accord to the finding that $\mathbb{N H}$ has no effect on heart rate.

In conclusion, $\mathbb{I N H}$ possesses a positive inotropic effect, which is not through the activation of betaadrenoceptor in the heart, but may be through the prolongation of depolarization of the myocardial cells by blocking of $\mathrm{K}^{+}$channels. Further experi-ments are needed to confirm this hypothesis.

\section{REFERENCES}

1. Mair FS, Crowley TS, Bundred PE et al. Prevalence, aeteology and management of heart failure in general practice. Br J Gen Pract, 1996; 46: 77-9.

2. Massie BM. 15 years of heart failure trials: what have we learned? The Lancet, 1998; 352 (Suppl I): 29-33.

3. Thesleff S. Aminipyridines and synaptic transmission. Neuroscience, 1980; 5: 1413-9.

4. Freeman SE, Lau WM and Szilagyi M. Blockade of a cardiac $\mathrm{K}+$ channels by tacrine: interaction with muscarinic and adenosine receptors. Eur J Pharmacol, 1988; 154: 59-65.

5. Morgan JP, Perreault CL and Morgan KG : The cellular basis of contraction and relaxation in cardiac and vascular smooth muscle. Am Heart J. 121; 961; 1991.

6. Soni M \& Kam P : 4-aminopyridine - a Review Anaeth Intensive Care, 1982: 10: 120-6.

7. Garcia De Jalon PD, Martinez-Sierra R and Velasco A : Interaction between tyramine and iproniazid on guineapig atria. B J Pharmac, 1973; 48: 609-11.

8. Mandell GL and Sande MA. Drugs used in the chemotherapy of tuberculosis and leprosy. In: The Pharmacological Basis of Therapeutics. Eds: AG Gilman, LS Goodman, TW Rall \& F Murad. Chapter 53, Mac Millan Pub Co. New York, 1990.

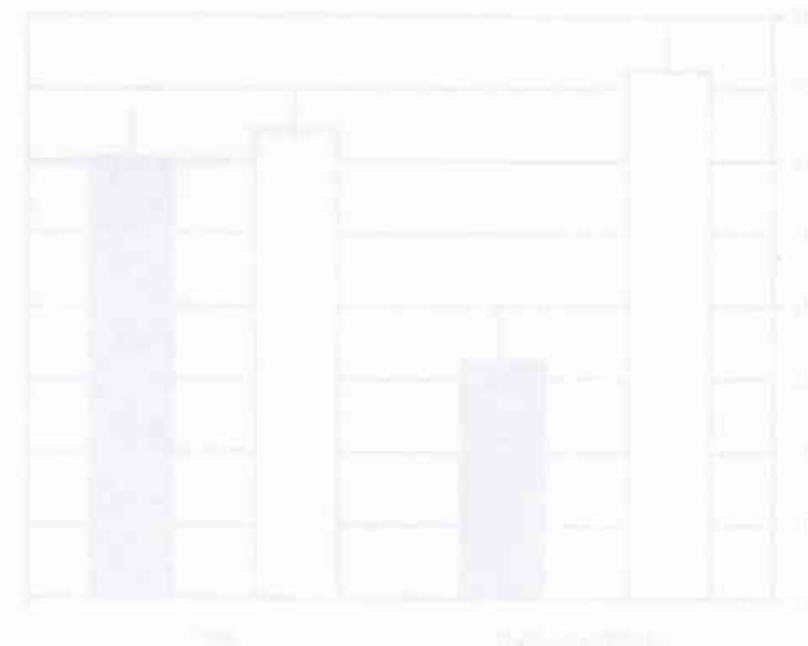

